\title{
Chloroclystis v-ata relicta ssp. n. (Lepidoptera, Geometridae), a new taxon from SW Finland, doomed to go extinct?
}

\author{
Harry Krogerus
}

\begin{abstract}
Krogerus, H. 1996: Chloroclystis v-ata relicta ssp. n. (Lepidoptera, Geometridae), a new taxon from SW Finland, doomed to go extinct? —Entomol. Fennica 7:63-66.

An isolated population of Chloclystis v-ata (Haworth, 1809), occurring at Karkali Peninsula, a nature reserve in southwestern Finland, is described as a new subspecies, ssp. relicta ssp.n., on the basis of differences in appearence and phenology compared to the nominate subspecies. The Central European population of $C h$. v-ata has been expanding to the north, reaching the Baltic Sea area in recent decades and Finland in 1985. Thus, the new subspecies which is actually protected by law is now threatened by hybridization with the nominate subspecies. In contrast to the bivoltine nominate subspecies, the Karkali population is univoltine. The biology of the new subspecies is discussed.
\end{abstract}

Harry Krogerus, Björneborgsvägen 5 P, FIN-00350 Helsingfors, Finland

Received 10 March 1995, accepted 19 October 1995

\section{Introduction}

In the world, many small populations, or subspecies or species with restricted distributions, are in danger of losing their genetic character due to hybridizing with closely related widespread populations of expansive nature (D. Simberloff, pers. comm.).

The geometrid species Chloroclystis v-ata (Haworth, 1809) (= Ch. coronata Hübner, 1813) was found for the first time in Finland in 1948. The first specimen, a male, was collected from a lime tree (Tilia) trunk on Karkali Peninsula in Karislojo (Karjalohja), southwestern Finland. The find was unexpected as there were only a few records of the species from northern Europe. No finds were known from Sweden or Denmark. The species was, however, recorded at Oslo-fjord in southern Norway in
1916 (e.g. Juul 1948, Fibiger \& Svendsen 1981) and in southeastern Estonia in 1940 (Sulcs \& Viidalepp 1972). The species is widespread in the Palaearctic. It has been recorded from Ireland and Portugal in the west through central and southern Europe, southern Russia and the Caucasus to Iran, India and China, and Siberia, Manchuria, Primorye and Japan (as ssp. lucinda Butler, 1879) in the east.

The Karkali Peninsula is characterized by exceptionally rich vegetation with several southern deciduous trees and many rare plant species. At the collecting site of the first $C$. $v$-ata specimen Tilia cordata, Quercus robur, Corylus avellana and Lonicera xylosteum dominate the tree and bush layer; the vegetation in the field layer is unique in Finnish conditions with plants like Mercurialis, Actaea, Pulmonaria, Viola mirabilis and Milium. The area was declared a nature reserve in 1961. 


\section{Observations and expansion in more southern areas}

Monitoring during 1950-1993 has shown that $C h$. $v$-ata has a permanent population in the Karkali Peninsula. The area occupied by the population is, however, only about three hectares along a SWdirected steep rock ridge. At the end of the $1970 \mathrm{~s}$ and the beginning of the 1980 s, the population of the moth appeared to be very small, but from 1985 onward the population has increased, and e.g. in the summers of 1992 and 1993 the species was abundant. The moth was legally protected in 1989.

During recent decades $C h$. $v$-ata has been expanding in North Europe. It was found for the first time north of Berlin in 1954 in Zehdenick (Urbahn 1964). The species was recorded in Denmark for the first time in 1973 (Torp 1974). It rapidly established itself there and occurred abundantly in the 1980s (Fibiger \& Svendsen 1981). The first Swedish specimen was found in 1976 in Scania (Elmqvist 1978), and the species was reported from several provinces in southern Sweden in the 1980s (Palmqvist $1985,1986,1987)$. In southern Norway the species was recorded in 1947 and 1955. Expansion is also taking place in the Baltic countries; the species was recorded in Lithuania in 1962 and in Latvia in 1963 (Sulcs \& Viidalepp 1972, Fibiger \& Svendsen 1981, Mikkola et al. 1989). The expansion has reached Finland, too: the first specimen outside Karkali was found on 21.-22.7.1985 at N: Sibbo, Spjutsund (M. Landtman leg.).

\section{Taxonomy}

The specimens collected at Karkali Peninsula differ externally in several respects from the expanding Central European taxon, including the specimen from Sibbo, but no differences in the genitalia have been found. In addition, the flight periods as well as the habitats appear to differ between the populations. The population of Ch.v-ata of Karkali is hereby described as

\section{Chlorocystis $\nu$-ata relicta ssp. $\mathrm{n}$.}

Etymology. From the supposed relict nature of the occurrence (see below).
Diagnosis. The ssp. relicta differs externally from the nominate subspecies by its smaller size (see below), paler bluish-green ground colour of forewing with silky sheen that is absent in the nominate subspecies, and weaker wing pattern. The pale subterminal line, clearly visible in the nominate form, is absent or very indistinctly marked by suffuse pale spots. The dark spots of fringe are weak, whereas in the nominate form they are distinct and contrasting. In ssp. relicta, the hindwing is pale silky green, often with unclear grey postmedial line, while in the nominate form the hindwing is darker grey with two or three indistinct transverse lines. The new taxon resembles ssp. lucinda Butler from Japan and the Far East but the latter is more brightly green.

Description. Wingspan: $\sigma^{7}$ average $13.7 \mathrm{~mm}$ (range 12.5-14.5, $\mathrm{N}=22$ ), q $15.5(14.0-17.0$, $\mathrm{N}=13$ ) (nominate subspecies: $0^{\top} 16.1,16.0-16.5$, $\mathrm{N}=3$; $917.6,17.5-18.5, \mathrm{~N}=4$ ). Ground colour of forewing pale greyish green with silky sheen. Dark pattern fine and not strongly contrasting against ground colour. Antemedian line narrow but distinct. Costal part of postmedial line blackish grey, forming sharp angle outward on vein $\mathrm{R}$, weaker toward dorsum. Subterminal line absent or very indistinctly marked by suffuse white spots. Fringe with weak dark spots. Hindwing pale silky green, often with unclear grey postmedial line.

Material studied: Holotype: o', Finland 668:32 $A b$ : Karislojo 11.7. 1952 H. Krogerus leg. Deposited in Zoological Museum, University of Helsinki (Helsingfors), Finland. Paratypes: $210^{\top} \sigma^{\top} 180 \%$, all specimens being from the type locality, labelled Finland (or Fennia) $A b$ : Karislojo H. Krogerus leg. (deposited in Zoological Museum, University of Helsinki (Helsingfors): $80^{7} 0^{7} 90 \%$; in Coll. H. Krogerus, Helsingfors, Finland: $110^{7} 0^{7} 900$; in Coll. M. Fibiger, Sorö, Denmark: 10; in Coll. M. Landtman, Helsingfors, Finland: 10').

Biology. Several adult specimens have been collected during the daytime, flushed from their day-resting sites on oak and lime tree trunks. A few specimens were found flying actively late after midnight. No specimens have been collected with light. The flight period appears to be from the last week of June to the first week of July, the earliest and latest collecting dates being 21.6.1993 and 17.7.1952.

The species has been reared ex ovo several times. In the first experiment (Krogerus 1962), the 
ENTOMOL. FENNICA Vol. 7:99. 20.IX.1996

\section{Errata}

Vol. 7, No 1, 1996, p. 36

In "Larval niche differences between the sibling species, Drosophila montana and D. littoralis (Diptera) in northern Finland" by Jouni Aspi (Entomologica Fennica 7: 36) the figure 5 was incorrect. The correct figure is reproduced below.

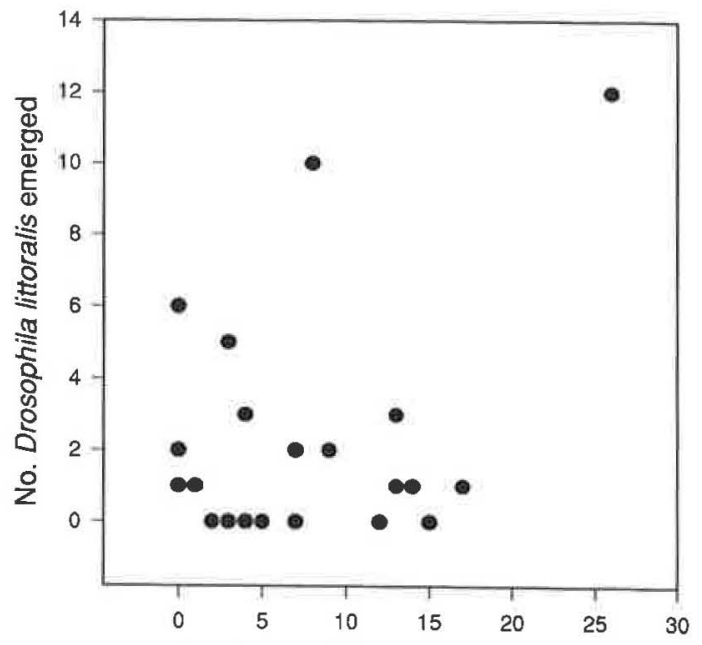

No. Drosophila montana emerged

Fig. 5. Association between the numbers of flies emerging from the yellow water lily substrate vials in Drosophila montana and $D$. littoralis. 

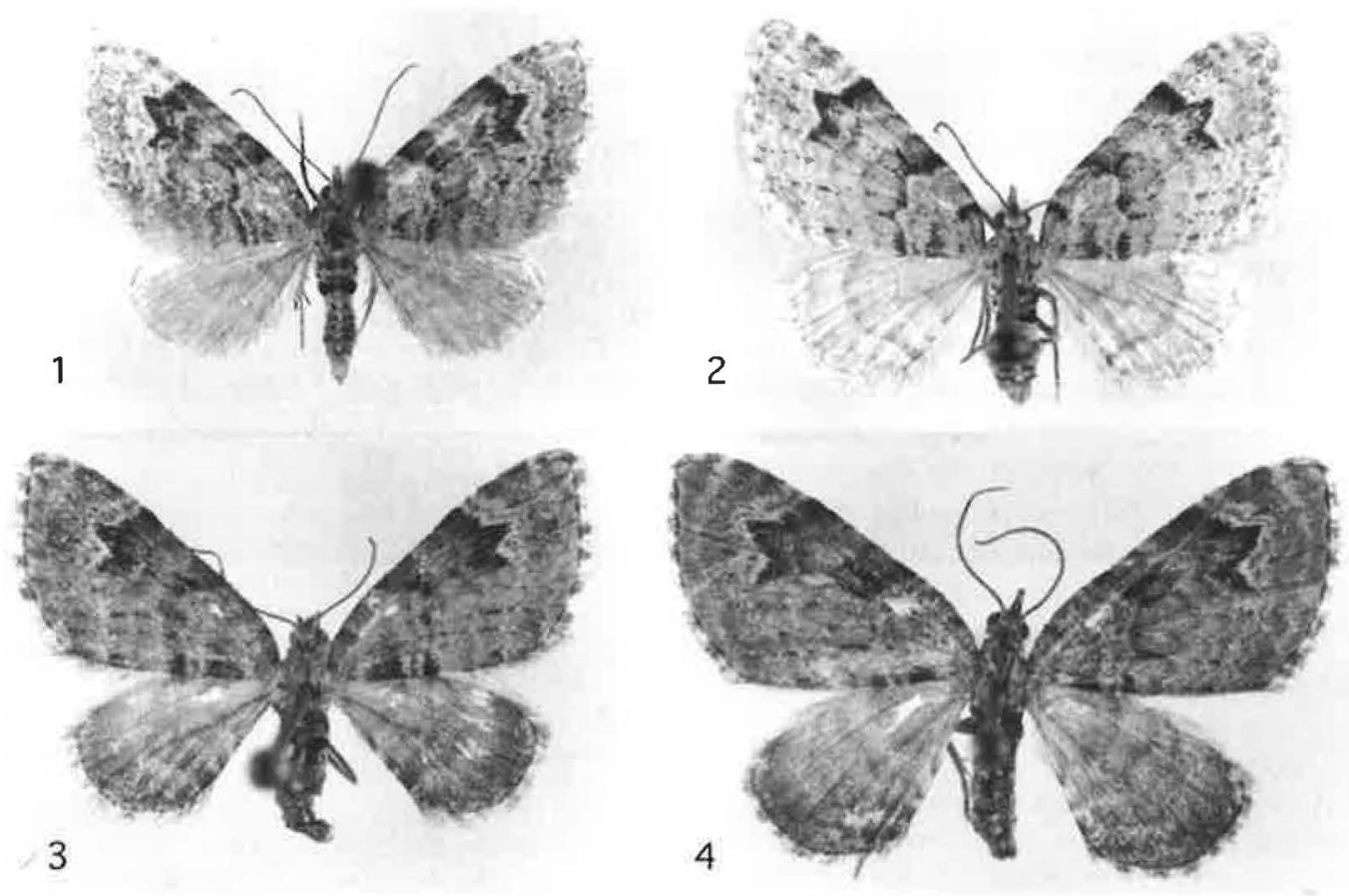

Fig. I-4. - 1: Chloroclystis v-ata relicta ssp.n., holotype ơ, Finland, Karkali. - 2: Chloroclystis v-ata relicta ssp.n., paratype o, Finland, Karkali. - 3: Chloroclystis v-ata v-ata (Haworth). ơ, Denmark, Mellemskov. - 4: Chloroclystis v-ata v-ata (Haworth). Q, Denmark, Gedesby.

larvae were fed with leaves and flowers of lime, as the females were found resting on trunks of that tree; the larvae appeared to be cannibalistic. In later experiments the leaves of all plant species growing in the habitat of Ch. $v$-ata were offered to the larvae, as well as some plant species mentioned in the literature as food plants of the species. The larvae clearly preferred the leaves of Eupatorium cannabinum (Asteraceae), which does not occur in the region. The most probable host plant in Karkali appears to be Mercurialis perennis (Euphorbiaceae).

Both the ground colour and pattern of the larva of Ch. v-ata are variable (cf. Juul 1948). The young larva of ssp. relicta is yellowish white with three black longitudinal lines, the dorsal line straight, lateral lines undulate. In the fully grown larva, the ground colour is dorsally pale brown, laterally yellowish brown, with bright yellow intersegmental rings. Every segment, except the first one, contains a brown triangular spot. The ground colour of some larvae is greenish up to the last instar. The length of the larval period is around three weeks. The larva pupates at the beginning of August and the pupa hibernates in the litter.

\section{Discussion}

The new subspecies seems to be strictly univoltine, flying in late June and early July. In central Europe the species is bivoltine, the flight period of the generations being from the beginning of May to the end of June, and from the end of July to August (Fibiger \& Svendsen 1981). Skou (1984) mentions mid-May to mid-June and mid-July to late August. The offspring of the summer brood pupates in the autumn and the pupa hibernates.

The isolated population inhabiting Karkali is most probably a relict one from the warm Litorina period 7000 years ago. Several other isolated plant and animal populations that are considered to be relics, e.g. the plant species Hypericum montanum and Cirriphylum tenuinerve, the gas- 
tropod Cochlodina orthostoma, the beetles Leiopus punctulatus and Pseudanostirus globicollis and a moth, Aplota kadeniella (HerrichSchaeffer), are known around Karkali and Lake Lojo (Lohjanjärvi).

The fate of this interesting taxon is alarming. The single specimen of the nominate subspecies of Ch. v-ata from Finland may have been a windblown individual but, if the taxon invades the country, which seems unavoidable, there are no means to prevent it from crossing with ssp. relicta. We can see only two ways in which the taxa would not hybridize: (1) the different phenology would keep them as parapatric populations or (2) they would have differentiated at species level and would be genetically imcompatible. Both alternatives seem improbable.

Acknowledgements. Michael Fibiger is acknowledged for placing Danish material at my disposal. I also thank Lauri Kaila who took the photographs and translated my manuscript into English, and Kauri Mikkola who made valuable comments on the manuscript.

\section{References}

Elmqvist, H. 1978: Det svenska fyndet av Chloclystis v-ata Hw. (Lep., Geometridae). —Entomol. Tidskr. 99:109-110.

Fibiger, M. \& Svendsen, P. 1981: Danske natsommerfugle. Aendringer i den danske natsommerfuglefauna i perioden 1966-1980. - Dansk Faunistisk Bibliotek. Bind 1. Klampenborg.

Juul, K. 1948: Nordens Eupithecier. - Aarhus, 145 pp.

Krogerus, H. 1962; Överraskande beteende hos larven av Dyserga coronata. — Notulae Entomol. 42:97.

Mikkola, K., Jalas, I. \& Peltonen, O. 1989: Suomen perhoset. Mittarit 2. - Hanko, 280 pp.

Palmqvist, G. 1985: Intressanta fynd av Macrolepidoptera i Sverige 1984. - Entomol. Tidskr. 106:65-70.

- 1986: Intressanta fynd av Macrolepidoptera i Sverige 1985. - Entomol. Tidskr.107:65-69.

- 1987: Intressanta fynd av Macrolepidoptera i Sverige 1986. - Entomol. Tidskr. 108:135-139.

Skou, P. 1986: Nordens målere. Danmarks Dyreliv 2. Köbenhavn \& Svendborg.

Sulcs, A. \& Viidalepp, J. 1972: Verbreitung der Grosschmetterlinge im Baltikum. - Deutsche Entomol. Z. N.F. 19:151-209.

Torp, R. 1974: Ny dansk måler Chloroclystis v-ata Hw. Lepidoptera, Bd. 2, pp. 203-206.

Urbahn, E. 1964: Verzeichnis von Schmetterlingarten die zunächst besonders zu beachten und zur Kartierung zu melden sind. — Entomol. Ber., Berlin 1964:41-45. 